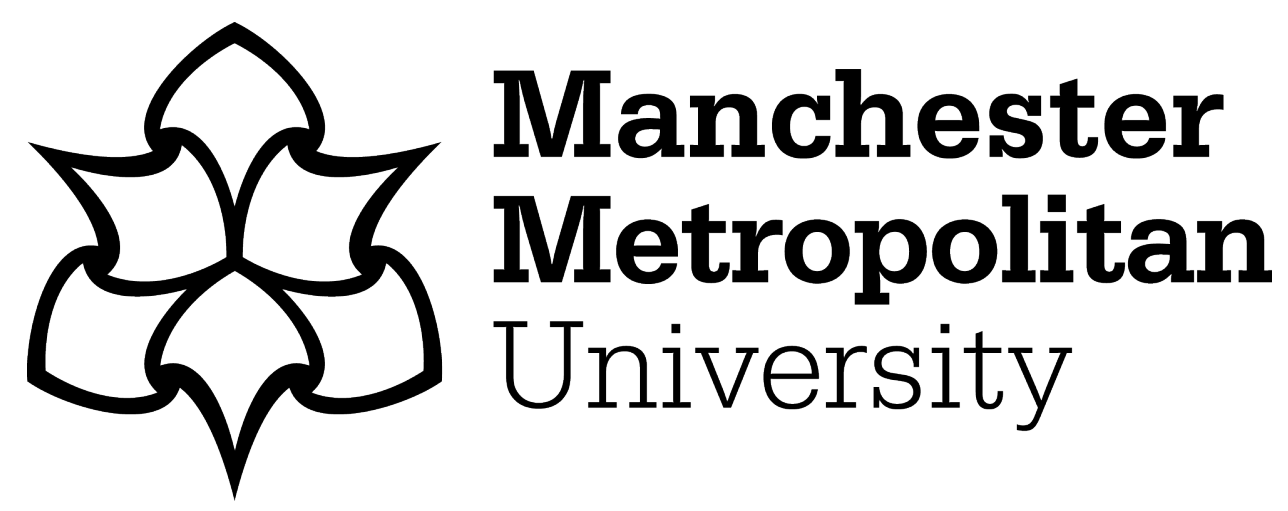

Van Ewijk, Anne Rienke, Nabi, Ghulam ORCID logoORCID: https://orcid.org/0000-0001-5645-5176 and Weber, Wiebke (2021) The provenance and effects of entrepreneurial inspiration. International Journal of Entrepreneurial Behavior \& Research, 27 (7). pp. 1871-1890. ISSN 1355-2554

Downloaded from: https://e-space.mmu.ac.uk/628355/

Version: Accepted Version

Publisher: Emerald

DOI: https://doi.org/10.1108/ijebr-02-2021-0099

Please cite the published version 
This is the author accepted manuscript (the version submitted and accepted for publication, before proofing by the International Journal of Entrepreneurial Behavior and Research). Please always refer to this manuscript as:

Van Ewijk, A.R., Nabi, G. and Weber, W. (2021) The provenance and effects of entrepreneurial inspiration, International Journal of Entrepreneurial Behavior \& Research, Vol. ahead-of-print No. ahead-of-print. https://doi.org/10.1108/IJEBR-02-2021-0099

\title{
The Provenance and Effects of Entrepreneurial Inspiration
}

\begin{abstract}
Purpose - Building on authoritative studies on inspiration in the field of psychology (e.g. Thrash and Elliot, 2013; 2014), this study aims to clarify how entrepreneurial inspiration - an emotional state of personal attraction towards entrepreneurship - is created and how it affects entrepreneurial intentions. First, receptiveness to inspiration is introduced as a potential entrepreneurial feeling trait that constitutes a universal enabler of entrepreneurial inspiration alongside typically idiosyncratic inspirational triggers. Second, this study proposes to reinforce the theoretical base of the relation between entrepreneurial inspiration and entrepreneurial intentions by applying the Affect Infusion Model - AIM (Forgas, 1995) - and empirically testing its explanatory power.

Design/methodology/approach - Hypotheses are tested through independent and dependent sample t-tests and hierarchical regression analyses with an interaction effect. Data originate from a pre-post course survey among 342 entrepreneurship students from various countries and institutions.

Findings - The results confirm a positive relation between receptiveness to inspiration and entrepreneurial inspiration. Receptiveness to inspiration precedes and increases with entrepreneurial experience, suggesting that it can be both inborn and cultivated. In line with the AIM, entrepreneurial inspiration stimulates only the entrepreneurial aspirations of participants without entrepreneurial experience. Experienced individuals, on the other hand, derived more entrepreneurial inspiration from their courses, but this was not translated to higher entrepreneurial intentions. Instead, they could benefit from this inspiration in other ways proposed in the literature, such as enhanced opportunity recognition.
\end{abstract}


Originality - This study provides much needed, theory-informed, insight into the formation of entrepreneurial inspiration. Furthermore, it is the first research to propose and test a specific theoretical underpinning of the relation between entrepreneurial inspiration and entrepreneurial intentions, which also accounts for the moderating role of entrepreneurial experience. Finally, the rare multi-country, multi-institution nature of the sample reinforces the external validity of the findings.

Key words: inspiration; emotion; entrepreneurship education; entrepreneurial intentions Article classification: Research Paper

\section{Introduction}

The term 'entrepreneurial emotions' refers to feelings or moods that are antecedent to, concurrent with, and/or a consequence of entrepreneurial activity; these emotions play a crucial role yet remain under-researched (Cardon et al., 2012; Nabi et al., 2017). In particular, the emotion of entrepreneurial inspiration deserves more attention. Previous studies - typically in the domain of entrepreneurship education - define entrepreneurial inspiration as "a change of hearts and minds evoked by events or inputs from the programme and directed towards considering becoming an entrepreneur" (Souitaris et al., 2007: 573). These (rare) studies assert that entrepreneurial inspiration positively affects students' entrepreneurial intentions more than any other outcome of entrepreneurship education (Nabi et al., 2018; Souitaris, 2007) and that entrepreneurial inspiration positively mediates the impact of entrepreneurship education on students' ambitions towards entrepreneurship while other entrepreneurial emotions do not (Haddoud et al., 2020). Furthermore, entrepreneurial inspiration enables individuals to recognition and exploit entrepreneurial opportunities more rapidly and effectively (Wartiovaara et al., 2019). While providing groundbreaking contributions on the role of entrepreneurial inspiration, the field is still left with two important unanswered questions.

First, how can one predict whether an entrepreneurship program, training, or course triggers entrepreneurial inspiration, while these triggers are highly idiosyncratic? As McAdams demonstrated already in 1982, there are no universal triggers for inspiration. And a recent study 
adds that the same triggers in fact inspire some and demotivate others (Nabi et al., 2018). This makes it hard to predict whether attempts in creating entrepreneurial inspiration will be successful, and among which participants.

Second, how and under which conditions does entrepreneurial inspiration increase entrepreneurial intentions, if at all? Previous empirical studies produced different findings on the relation between these two concepts. Souitaris et al. (2007) found that entrepreneurial inspiration was a determinant of post-course entrepreneurial intentions. Haddoud et al. (2020) demonstrate how entrepreneurial inspiration is a mediator of the impact of entrepreneurship education on entrepreneurial intentions. A mixed-method study by Nabi et al. (2018) illustrates how inspiration enhanced entrepreneurial intentions for some, but not all, university students. What makes it more difficult to interpret this disparity, is that none of these studies provide a robust theoretical framework explaining the relation (Keller and Kozlinska, 2019). Souitaris et al. (2007) base their expectation on common logic: considering an option (the target part of inspiration) is likely to be the first step to changing attitudes and intentions towards entrepreneurship. In line with that explorative stance, Nabi et al. (2018) investigate whether there are different types of inspiration, positive and negative, which can lead students towards or away from entrepreneurship. However, their focus lies on developing a qualitative typology, rather than testing a-priori theory. Haddoud et al. (2020) only briefly mention Social Cognitive Theory and the importance of role models.

To answer these questions, this study aims to provide more insight into the origins and role of course-derived entrepreneurial inspiration by developing and testing a series of theory-derived hypotheses. This starts by emphasizing the conceptual distinction between trait inspiration as 'receptiveness to inspiration' (Thrash and Elliot, 2003) and state inspiration as the experience of feeling inspired. Receptiveness to inspiration is then introduced as a potential entrepreneurial trait (Brandstätter, 2011; Kerr et al., 2018) that makes individuals more likely to feel inspired, regardless of which triggers the context provides. First, the researchers assess whether receptiveness to inspiration is higher for participants with or without actual entrepreneurial experience, thus addressing the concern that entrepreneurial trait studies rarely explore causality (Kerr et al., 2018; Kuratko, 2010; Mitchell et al., 2002). Second, the Affect Infusion Model - AIM (Forgas, 1995) is proposed and tested as comprehensive explanatory framework for the relationship between course-derived inspiration and entrepreneurial intentions. According to the AIM, affect can infuse cognition, and this occurs more often in complex situations where 
information is new and concerns an unfamiliar topic that might have a considerable personal impact. Applying this model to this research presupposes that course-derived entrepreneurial inspiration (a discrete emotion, affect) influences entrepreneurial intentions (cognition), but only for those without previous entrepreneurial experience who are just starting to become aware of a choice for or against an entrepreneurial career (complex and new situation). The trait-state inspiration dichotomy in combination with the Affect Infusion Model helps sheds light on the previously outlined disparate findings by providing future studies with an unprecedented comprehensive theoretical framework that connects receptiveness to inspiration with coursederived entrepreneurial inspiration and entrepreneurial experience.

Subsequently, the hypotheses are elaborated in the theoretical background. Then, the methodology and results are outlined, after which the implications of the results are discussed in the context of existing literature, alongside a consideration of the limitations of the study and suggestions for future research. The paper closes with a conclusion that summarizes the main findings.

\section{Theoretical Background and Hypotheses}

\section{Inspiration}

Inspiration is a familiar, yet multifaceted, phenomenon. A writer can feel inspiration from above when immersing herself in a spiritual retreat. A casual conversation with a guest lecturer after the seminar can inspire an engineer to develop an innovative product. A student might be inspired to develop a support program after reflecting on her own experiences in overcoming a difficult period in her life. An unexpected role model can inspire one towards a career possibility that would otherwise not have been recognized. Whether inspiration comes from above, from within, or from around us, it is generally defined as a specific mental process that facilitates learning and development (Williams, 1997), accompanied by a combination of emotions, such as elevation (Haidt, 2000), awe and admiration (Keltner and Haidt, 2003). Inspired individuals feel energized, overtaken, intrigued and focused. Fueled by this emotion, their reasoning transcends ordinary preoccupations about limitations of human agency towards achieving a new goal (Thrash and Elliot, 2003; Thrash et al., 2014).

While inspiration is relevant in many disciplines, the field of psychology has built the most sophisticated and empirically supported conceptualizations (Wartiovaara et al., 2018). Thrash and 
Elliot $(2003,2004)$ laid the groundwork for dissecting and understanding inspiration. The most fundamental distinction in their work is the conceptual difference between state inspiration versus trait inspiration (Thrash et al., 2014).

\section{State Inspiration: Feeling Inspired}

State inspiration falls under the category of state emotions (Grichnick et al., 2010) or feeling states (Keller and Kozlinska, 2019), referring to a current affective feeling, manifested in either discrete emotions (intense for a limited time and it have a salient object) or moods (also temporary, but more long term, state of mind). In line with previous studies mapping lay conceptions of feeling inspired, Trash and Elliot introduce (2003) and elaborate (2004) a tripartite conceptualization of state inspiration, presenting three core characteristics: evocation, transcendence, and motivation. Evocation implies that inspiration overcomes us, triggered by internal or external stimuli, such as ideas, experiences, people, works of art, etc. Transcendence refers to the fact that inspiration helps someone see better possibilities that are beyond one's usual concerns. Finally, inspiration involves motivation to express or implement these possibilities. As such, state inspiration includes the process of feeling 'inspired by' as well as feeling 'inspired to' (Thrash and Elliot, 2004; Souitaris et al., 2007; Wartiovaara et al., 2018).

State inspiration can be meaningfully and significantly differentiated from related concepts, such as positive affect and intentions. While positive affect is a purely emotional construct, state inspiration involves both emotional and cognitive processing. Moreover, state inspiration turned out to be much more volatile than positive affect, diminishing in weekends while positive affect remained relatively stable throughout the week (Thrash and Elliot, 2004). Similarly, Souitaris et al. (2007) argued that feeling drawn to and considering an option - inspiration - does not necessarily mean deciding to pursue it - intentions. Their empirical results confirmed the independence of the constructs they used to measure these two concepts.

In line with the traditional and dominant interpretation of inspiration as something that overcomes us (Clarke, 1997), studies on the role of inspiration in the creative process (Oleynick et al., 2014), in entrepreneurship (Wartiovaara et al., 2018) and in entrepreneurship education (Haddoud et al., 2020; Nabi et al., 2018; Souitaris et al., 2007) all focused on state inspiration, typically triggered by external stimuli. Applying state inspiration to the field of entrepreneurship education led to the introduction of course-derived entrepreneurial inspiration as "a change of 
hearts and minds evoked by events or inputs from the programme and directed towards considering becoming an entrepreneur" (Souitaris et al., 2007: 573). Although this definition is congruent with the concept of state inspiration in the sense that it relates to both triggers and target (Thrash and Elliot, 2004), the measures designed and used to capture entrepreneurial inspiration in the first ground-breaking empirical studies (Haddoud et al., 2020; Nabi et al., 2018; Souitaris et al., 2007) can be improved further as all of them rely on specific example triggers (see 'Measures' in the Methods section), while these are highly idiosyncratic and can even have opposite effects (McAdams 1982; Nabi et al., 2018; Thrash et al., 2014). This makes it challenging for instructors to predict to what degree they can be successful in stimulating entrepreneurial inspiration. Reverting to the largely ignored concept of trait inspiration can shed more light on the provenance of course-derived entrepreneurial inspiration.

\section{Trait Inspiration: Being Inspirable - Receptiveness to Inspiration}

In a classic compilation of 17,953 terms to describe personality, Allport and Odbert (1936) classified inspirable as a trait descriptor, inspired as a temporary state, and inspirational as a social evaluation. Inspired by this analysis, Thrash and Elliot (2003) suggested that inspiration may be viewed as a trait or as a state. Trait inspiration, then, is a level of analysis that is somewhat removed from the experience itself (Thrash and Elliot, 2004). To facilitate studies on this neglected concept, Thrash and Elliot (2003) developed and validated the Inspiration Scale (IS), a general measure of trait inspiration. The IS was found different from various converging motivation and trait constructs, such as positive affect, intrinsic motivation, openness to experience, optimism and selfesteem (Thrash and Elliot, 2003). To avoid confusion with the much more common understanding of inspiration as a state, trait inspiration is labelled as 'receptiveness to inspiration'. Receptiveness to inspiration is a chronic affective feeling, a tendency to emotionally respond to situations in a stable, predictable manner (Barsade and Gibson, 2007), also called a feeling trait (Keller and Kozlinska, 2019).

Compared to emotions or moods, traits are relatively more stable over time and within different contexts (Conley, 1985), becoming even more consistent as people grow older (Roberts and DelVecchio, 2000). This does not imply that traits are permanently fixed. For example, a metaanalysis by Roberts et al. (2006) revealed how traits can undergo considerable change over the course of one's life. In addition, Roberts and Mroczek (2008) found unique patterns of personality 
trait development at all stages of people's lives, likely related to life-altering experiences, typically more prominent during young adulthood. Hands-on experience with entrepreneurship, such as starting a new venture or taking serious steps towards starting a venture (for example, putting time and attention into developing a business plan), seems likely to constitute an event sufficiently impactful to change personality traits (Bloemen Bekx et al., 2019). While the longstanding debate over whether entrepreneurs are 'born or made' remains unsolved (Kerr et al., 2018), previous entrepreneurial trait studies have emphasized that entrepreneurial experiences can function as a catalyst of certain personality traits. As part of the process dynamics in personality constructs for entrepreneurs (Frese and Rauch, 2008), being active in entrepreneurship makes individuals adopt, practice and reinforce entrepreneurial traits (Mitchell et al., 2002). For example, openness to experience is a common trait among entrepreneurs (Wartiovaara et al., 2018). At the same time, openness to experience was found to be an important antecedent of trait inspiration (Thrash and Elliot, 2003). Similarly, then, receptiveness to inspiration, as a feeling trait and potential entrepreneurial trait, is likely to increase when individuals experience entrepreneurial achievements and become more confident in their ability to be inspired (cf. Rae, 2000). Therefore, the expectation is that:

H1. Receptiveness to inspiration is higher for individuals with entrepreneurial experience than for those without.

\section{Receptiveness to Inspiration as Antecedent of Course-Derived Entrepreneurial Inspiration}

Thrash and Elliot (2003) demonstrated that receptiveness to inspiration, captured in the IS scale for general trait inspiration, predicted individuals' ongoing, daily experiences of inspiration, even when other trait and daily covariates were controlled. The conceptual model by Hart (2000) helps explain this relation. According to Hart (2000), three situational components shape inspiration as an epistemic event (that is, state inspiration): contact and connection, openness and receiving, and vibrancy and clarity. In other words, for inspiration to occur, sufficient (1) opportunity, (2) receptiveness and (3) intensity must exist.

Previous studies in the field of entrepreneurship education (Haddoud et al., 2020; Nabi et al., 2018; Souitaris et al., 2007) focus on the component of opportunity (the input from an entrepreneurship course or program) and the component of intensity (the degree to which certain 
triggers were experienced as inspirational). This study posits that the third component from Hart's (2000) research - receptiveness - forms a generic threshold for the other two idiosyncratic components. Receptiveness to inspiration (a feeling trait) increases the likelihood that coursederived entrepreneurial inspiration (a discrete emotion) is formed, by augmenting the likelihood of individuals perceiving triggers for inspiration as positive and by governing how intense these triggers must be for individuals to feel entrepreneurial inspiration. As such, receptiveness to inspiration can be an affective contributor to the 'entrepreneurial mind-set' (see Heckman, 2008). Asides from 'the drive and ability to think critically about the needs and motivations of diverse stakeholders, to communicate with a wide array of audiences and in a variety of contexts, and to navigate an increasingly complex information landscape' (Blake Hylton et al., 2020: p.87), the entrepreneurial mindset embodies a commitment and ability to view the world from an innovative perspective, ultimately leading to more entrepreneurial behavior (Kuratko, 2010). From that perspective, the expectation is that:

H2. The higher receptiveness to inspiration (trait), the higher course-derived entrepreneurial inspiration (state).

\section{Course-Derived Entrepreneurial Inspiration and Entrepreneurial Intentions}

Pioneering studies on course-derived entrepreneurial inspiration all focus on its relation with students' entrepreneurial intentions (Souitaris et al., 2007; Nabi et al., 2018; Haddoud et al., 2020), without providing a clear theoretical underpinning for this relation. The Affect Infusion Model (Forgas, 1995) can address this gap. The Affect Infusion Model describes affect infusion as "a process whereby affectively loaded information exerts an influence on and becomes incorporated into the judgmental process, entering into the judge's deliberations and eventually coloring the judgmental outcome" (Forgas, 1995: 39).

While affect will have less influence on the reproduction of stored reactions, referring to more or less automatic responses that were also given to similar situations in the past, it is most influential in complex situations with new information on an unfamiliar topic that might have a considerable personal impact. In those situations, affect influences all stages in the social cognition process. First, affect infuses attention: individuals are more likely to pay attention to information that is congruent to the affect than to information that is incongruent. Second, affect influences 
encoding: individuals spend more time connecting affect-congruent information to other important considerations. Third, affect stimulates retrieval: affect-congruent information is more likely to be remembered. Fourth, affect primes associations: the type of affect can determine what associations - with previous experiences, events, and other people - come to mind when processing complex information and these associations subsequently influence the interpretation of that information and the final judgment (Forgas, 1995). Concept priming is a key notion of affect infusion. It assumes that current emotions serve as the basis for judgmental processes because they prime emotion-congruent memories: the more positive the emotions are, the more positive the evaluation is (Grichnick et al., 2010).

Several studies provide empirical support for this theory. For example, Clore et al. (2001) found that affect plays a role in general decision-making, while Davis et al. (2007) demonstrated how affect influences goal setting. In the field of entrepreneurship, Foo et al. (2009) discovered that venture efforts increase when affect is positive, and Rivis et al. (2009) confirmed feelings regarding the anticipated effect as a significant predictor of entrepreneurial intentions.

Translated to the present study, affect infusion implies that individuals who feel entrepreneurial inspiration are primed to focus on information that makes them see the process of becoming an entrepreneur themselves in a positive light. They are more likely to remember input that confirms this vision, and they are quicker to associate triggers for inspiration with other positive experiences or people in their life. As a result, this process increases their entrepreneurial aspirations. However, affect infusion is most likely to occur when information is new, and the final judgment has a large potential impact on a person's life (Forgas, 1995). This is not the case for students with entrepreneurial experience. They might still be inspired by the course regarding, for example, new product design - or it might help their ideas evolve from a raw idea to a refined idea (Clausen, 2020). However, the idea of entrepreneurship is not new for them and that makes the concept of 'intention to become an entrepreneur' less relevant. This refinement regarding the effect of course-derived entrepreneurial inspiration was not part of the scope of previous studies (Nabi et al., 2018; Souitaris et al., 2007). Thus, while controlling for entrepreneurial intentions at the start of the course, it is important to assess whether:

H3. Course-derived entrepreneurial inspiration increases entrepreneurial intentions only for individuals without entrepreneurial experience. 
[Figure 1 near here]

\section{Methods}

\section{Sample and Data Collection}

The sample consists of 342 undergraduate and graduate business and engineering students from various universities and countries, who responded to a survey at the start and at the end of their entrepreneurship course, an essential component of entrepreneurship education impact studies (Fayolle et al., 2016). A check for attrition bias revealed no significant differences between oneand two-time respondents. Table I provides more details regarding the composition of the sample.

[Table I near here]

Several researchers have denounced the lack of studies drawing samples from multiple geographical areas (Blenker et al., 2014; Lorz et al, 2013). Specifically, it is observed that most studies originate from the US and Europe (predominantly from the UK) and far fewer are executed in Asia, Africa and Latin-America (Nabi et al, 2017; Pittaway and Cope, 2007). Focusing on entrepreneurship students within one single context severely limits the external validity of the results: to what extent outcomes can be generalized cannot be ascertained (Blenker et al, 2014; Lorz et al., 2013). Thus, through various academic international conferences and associations entrepreneurship instructors around the globe received a call for student participation. During this study, 'course' referred to a single module of classes, with at least 45 formal face-to-face contact hours spread out equally over the term or semester as per the different academic calendars (sixtwelve weeks). While the limitations of this type of convenience sampling are well-known, a review of the course syllabi - collected after the end measurement for each course - indicated that the sample was suitable for this study in the sense of the content of the courses: all courses focused on individual characteristics of entrepreneurs as well as on the process of starting up a business, both in theory and in practice. Furthermore, the entrepreneurship courses were largely similar in terms of the use of formal teaching, case studies, business plan development and simulation in groups. 
Students' participation in the survey was anonymous, voluntary, and ungraded. The English questionnaire was reviewed by experts and non-experts, and pre-tested with a sample of the target population (accounting different linguistic origins) which was then excluded from the final data collection. The aim of the pre-tests was to optimize clarity of wording and face validity of the constructs to suit both native and non-native English speakers.

\section{Measures}

The scale for trait inspiration that was developed and validated by Thrash and Elliot (2003) can be used to capture receptiveness to inspiration. It contains four items: (1) I experience inspiration, (2) Something I encounter or experience inspires me, (3) I am inspired to do something, and (4) I feel inspired. Two questions accompany each statement: one about frequency (How often does this happen?) and one about intensity (How deeply or strongly (in general)?). The response options are given on a 7-point Likert scale for frequency (from 'never' to 'very often') and intensity (from 'not at all' to 'very strongly or deeply'). As in the original scale, the score for each item comprised the sum of scores for frequency and intensity. To re-assess the internal structure of the measures Cronbach's alpha was considered as the appropriate reliability indicator, when all items load equal on the latent concept - a tau-equivalent model (Viladrich et al., 2017). Otherwise, for congeneric models, the use of McDonald's omega is more appropriate (Viladrich et al., 2017). For receptiveness to inspiration, the four composite items loaded equal on the same latent concept, indicating a tau-equivalent model. With Cronbach's alpha at .86 at the start of the course and .85 at the end of the course, sufficient reliability was established.

Entrepreneurial intentions have been measured in various ways in previous studies, for example, using three items with a 7-point Likert scale (Kolvereid, 1996; Souitaris et al., 2007) or using ten items, of which four are distractors and not included, with a 6-point Likert scale (Nabi et al., 2018; Thompson, 2009). Following Souitaris et al. (2007), a questionnaire pilot was run with participants that were representative of the target sample: non-native English-speaking undergraduate students from different linguistic backgrounds. Adhering to participants' advice to include those items from previous scales that were most easily and uniformly understood, while capturing entrepreneurship as both being self-employed and starting up a venture, the final measure consists of seven previously validated items (Krueger et al., 2000; Liñán and Chen, 2009), of which two are reversed scoring. (1) My professional goal is to become an entrepreneur, (2) I 
prefer to be employed in an organization and not be an entrepreneur - R, (3) Being an entrepreneur would give me great satisfaction, (4) A career as an entrepreneur is totally unattractive to me - R, (5) I am very seriously thinking of starting my own venture or business, (6) If I had the opportunity and resources, I would love to start my own venture or business, (7) I am ready to do anything to become an entrepreneur. In line with the aforementioned previous studies, options for answering ranged from 'totally disagree' to 'totally agree' on a 5-points Likert scale. For this measure, a congeneric model appeared (not all factor loadings were equal), which suggests that McDonald's omega is the appropriate indicator. That said, McDonald's omega and Cronbach's alpha are very close (both .93), likely due to the high factor loadings ( $\geq .86$ ), all indicating sufficient internal consistency reliability.

While previously used measures of course-derived entrepreneurial inspiration proved useful (Haddoud et al., 2020; Nabi et al., 2018; Souitaris et al., 2007), each of them contains an important shortcoming. For example, Souitaris et al. (2007) asked participants if they remembered anything from the course that drastically changed their 'hearts and minds' and made them consider becoming an entrepreneur. They provided a list of example triggers to help respondents relate to the concept, although these were not included in the score for inspiration. That score was calculated by multiplying the answer to the binary question ( $0=$ no $1=y e s)$ with the answer to the follow-up question regarding the extent in which such events made the student consider becoming an entrepreneur (7-point Likert scale). Instead of this single-item scale, the authors themselves suggested future researchers to develop and validate a reliable multi-item scale of the construct. While Haddoud et al. (2020) chose to continue with the original measure, Nabi et al. (2018) adhered to the advice and developed a measure with five items in which they combined the main question with specific triggers, such as "In your first year at university, to what extent did any of the following particular events or inputs change drastically your 'heart and mind' and make you seriously consider an entrepreneurial career?: The views of a tutor/ lecturer" (6-point Likert scale). However, a measure for state inspiration ideally refers only to the context or situation that triggers presumably originate from, in this case the entrepreneurship course, without mentioning specific triggers, because different inspirational stimuli appear to have distinct effects on different people (Thrash et al., 2014). A trigger that blows one's mind away might not affect another person in the slightest (McAdams 1982), or even have opposite effects in the sense that the same trigger pushes 
some towards and deters others from a potential career as entrepreneur, as Nabi et al. (2018) concluded after analyzing their qualitative data.

Therefore, an alternative theoretically congruent multi-item scale was developed and tested. As state inspiration is a concept that is meaningful in individuals' lives and often uniformly understood (Hart, 1998) the measure must be straightforward and face valid (Thrash and Elliot, 2003). Thus, the following three items were included: (1) The course inspired me, (2) The course inspired me about entrepreneurship, and (3) The course inspired me to consider becoming an entrepreneur myself. As recommended by Thrash and Elliot (2004), this measure includes a generic reference to the processes of being 'inspired by' (items 1) and 'inspired to' (item 3), whereby the second item is a combination of both: the generic source is identified and the focal

object or direction is there, but the desired action is kept implicit. Referring to experiences during the course, this measure is only applicable at the end of the course. In line with the measure for entrepreneurial intentions, response options ranged from 'totally disagree' to 'totally agree', on a 5-points Likert scale. For this scale, a tau-equivalent model appears, whereby all factors load equal on the latent concept, making Cronbach's alpha the appropriate reliability indicator. The high factor loadings (of .81) and Cronbach's alpha of .87 also suggest that this measure is sufficiently reliable.

Finally, a principal component analysis was conducted for all continuous variables and all factors emerged with an eigenvalue higher than one, at both points in time, confirming the independence of the scales.

The last main variable, entrepreneurial experience or previous entrepreneurial exposure, was measured by asking students at the start of the course whether they had already started up their own business and/or whether they had already taken serious steps to prepare for starting-up a new enterprise, such as writing a business plan or applying for funding. Defining experience as broadly as possible, a score of one was computed for all students with one or two affirmations and a score of zero allocated to all other students.

\section{Control Variables}

In contrast to receptiveness to inspiration and course-derived entrepreneurial inspiration, there are many studies on entrepreneurial intentions in the field of entrepreneurship education (Fayolle et al, 2016; Nabi et al., 2017). This warrants a careful selection of control variables for all hypotheses 
regarding entrepreneurial intentions, based on considerations and findings from previous empirical studies. This includes entrepreneurial intentions at the start of the course (Souitaris et al., 2007), course characteristics such as whether the course is part of an entrepreneurship program and whether study level is undergraduate or postgraduate (Springer, 2009), whether the mode of course selection is compulsory or elective (Rideout and Gray, 2013), and whether the gender of the students is female or male (Van Ewijk and Belghiti-Mahut, 2019; Westhead and Solesvik, 2016). Table II provides a matrix indicating the overall correlations between the main study variables and the controls.

[Table II near here]

\section{Analyses and Findings}

Hypothesis 1: To examine whether receptiveness to inspiration is higher for respondents with entrepreneurial experience than for respondents without, an independent samples t-test based on the pre-intervention values (the scores at the start of the course) is appropriate. As illustrated in Table III, there is a significant difference in means, whereby the mean is higher for those with entrepreneurial experience, which is in line with Hypothesis One.

[Table III near here]

Hypothesis 2: While some sample characteristics suggest a three-level multilinear model (country, institution, individuals), the limited number of subsamples and reduced subsample sizes do not support this approach. Previous research prescribes at least 30 level-1 units with at least 10 groups for accurate fixed effects and standard errors, 30 groups if random effects are of interest, and at least 50 groups if accurate random effects and their standard errors are desired (Pacagnella, 2011; Schoeneberger, 2016). As a rule of thumb, Kreft (1996) suggests at least 30 groups with at least 30 individuals per group. McNeish and Stapleton (2016) provide a general review of the problems associated with having a small number of groups. Furthermore, preliminary analyses of the data (one-way ANOVA's) did not suggest meaningful significant differences in means between countries and institutions on the continuous variables at both points in time. Hence, a multiple 
hierarchical regression analysis is used to investigate whether receptiveness to inspiration (trait) is positively related to course-derived entrepreneurial inspiration (state). Compared to the base line with control variables only (Model 1), adding receptiveness to inspiration to the equation significantly increases the explained variance in course-derived entrepreneurial inspiration (Model $2, p<.001)$. This supports Hypothesis Two. From the control variables, a significant positive relation to whether the course is part of an entrepreneurship program or degree $(p<.05)$ can be observed. Table IV presents these results in detail.

[Table IV near here]

Hypothesis 3: To determine whether there is a significant interaction effect between the predictor and moderator on the dependent variable, a moderated regression analysis was run. Model Four in Table $\mathrm{V}$ indicates that this is the case $(p<.05)$ and it is pertinent to proceed to subgroup analysis. Table VI displays the results of the regression analyses for course-derived entrepreneurial inspiration on entrepreneurial intentions at the end of the course for students with and without entrepreneurial experience. Entrepreneurial intentions at the start of the course is the only control variable in with a significant positive relation to entrepreneurial intentions at the end of the course in all models $(\mathrm{p}<.001)$. Beyond that, there is a significant positive relationship between courserelated entrepreneurial inspiration and entrepreneurial intentions for students without entrepreneurial experience $(\mathrm{p}<.001)$, but not for the other students. Thus, Hypothesis Three is supported.

[Tables V and VI near here]

Post hoc analysis: While course selection mode (compulsory versus elective) did not have a significant effect on entrepreneurial intentions, the descriptive statistics showed how taking the course as part of a wider entrepreneurship program (such as a minor or major) was significantly related to course-derived entrepreneurial inspiration (Table II). Intrigued, the researchers conducted two independent samples t-tests by means of post-hoc analyses. The results indicated that students enrolled in a wider entrepreneurship program scored significantly higher on 
entrepreneurial intentions at the start of the course as well as on course-derived entrepreneurial inspiration than other students (Tables VII and VIII).

[Tables VII and VIII near here]

\section{Discussion}

The results give rise to four key theoretical contributions. First, Thrash and Elliot's (2003) psychological construct of receptiveness to inspiration is extended by examining the role it plays in a university entrepreneurship education context. No studies have examined receptiveness to inspiration amongst other university entrepreneurship education variables, such as course-derived entrepreneurial inspiration, entrepreneurial intentions, and entrepreneurial experience. This is meaningful as it contributes to the theoretical importance of how receptiveness to inspiration, as an entrepreneurial trait, can play a significant role in an entrepreneurship course, as it links positively to feelings of course-derived entrepreneurial inspiration.

Second, the results show that this trait, receptiveness to inspiration, is present among students without entrepreneurial experience, even though it was significantly higher among students with entrepreneurial experience. Previously, authors have suggested that it is important to infer causality (Brandstätter, 2011) and to find conclusive evidence for traits that push individuals into the domain of entrepreneurship instead of merely establishing which traits are more prominent among entrepreneurs (Kuratko, 2010). The findings of this study suggest, however, that a more nuanced posture towards cause and effect needs to be taken when it comes to the trait of receptiveness to inspiration: it is neither solely inherent nor solely consequential to entrepreneurial experience.

Third, the study integrated insights from psychology and philosophy (Thrash and Elliot, 2003, 2004; Hart, 2000) to explain how receptiveness to inspiration can increase the likelihood that students will be inspired about and towards entrepreneurship. It was the first to propose that relation, and the empirical results confirmed this expectation. In the process, an alternative multiitem measure for capturing course-derived entrepreneurial inspiration was developed, that is more theoretically congruent, with optimized face validity. This warrants and facilitates more entrepreneurship research on receptiveness to inspiration. 
Fourth, drawing on the Affect Infusion Model (Forgas, 1995), this study contributed to the emerging field of entrepreneurial emotions (Cardon et al., 2012) as well as to the field of entrepreneurship education (Souitaris et al., 2007; Nabi et al, 2018; Haddoud et al., 2020) by providing a much more robust theoretical underpinning of the relation between course-derived entrepreneurial inspiration and entrepreneurial intentions. As outlined in the theoretical framework, this model explains how affect (entrepreneurial inspiration) primes cognitive processes (entrepreneurial intentions) but only when information is new and related to possible life changes. The findings confirm that course-derived entrepreneurial inspiration was positively related to entrepreneurial intentions for unexperienced rather than experienced students, even though the latter students reported higher receptiveness to inspiration (Table III) and derived more course-derived entrepreneurial inspiration (Table II).

As such, the Affect Infusion Model (Forgas, 1995; Baron, 2008; Rivis et al., 2009) and effects of entrepreneurial inspiration (Thrash and Elliot, 2004; Wartiovaara et al., 2018) complement existing intention models that still dominate entrepreneurship and entrepreneurship education literature (Nabi et al., 2017), such as the Theory of Planned Behavior (Ajzen, 1991), the Entrepreneurial Event Model (Shapero and Sokol, 1982), and the Shapero-Krueger model of entrepreneurial intent (Krueger et al., 2000). Extending existing intention models to take the Affect Infusion Model into account might be a rewarding exercise. These models present various antecedents of entrepreneurial intentions, such as attitudes towards entrepreneurship (beliefs about personal costs and rewards of entrepreneurship), subjective norms (of family and friends towards entrepreneurship), perceived behavioral control (perceived ease or difficulty in being able to implement entrepreneurial behavior), or entrepreneurial self-efficacy (perceived ability to engage in entrepreneurial behavior). Concept priming, a key notion in the Affect Infusion Model, implies that emotions influence cognitive processes (Baron, 2008). The emotion of entrepreneurial inspiration is likely to correlate or positively influence attitudes towards entrepreneurship, as Thrash and Elliot (2003) found that inspiration is associated with elevated levels of optimism and positive affect. In addition, entrepreneurial inspiration has the potential to weaken (negatively moderate) the relation between subjective norms and entrepreneurial intentions, and between perceived behavioral control and entrepreneurial intentions: inspired individuals often become so absorbed into the new vision, that they are more likely to focus inwards and ignore external views, particularly information undermining or questioning his or her idea (Baron, 2014). In addition, 
future research could examine the extent to which entrepreneurial inspiration raises entrepreneurial self-efficacy, as this emotion also results in an extension of the self beyond one's perceived limitations through an enhanced self-image (Wartiovaara et al., 2018).

Finally, a noticeable new insight was generated regarding course type and entrepreneurial intentions when analyzing the results regarding control variables: participants who took their course as part of a specialization in entrepreneurship, such as a minor, major or master, reported significantly higher course-derived entrepreneurial inspiration than other students did. At the same time, the results did not show that students who had chosen to do the course (taking it as an elective) reported higher entrepreneurial intentions, on average, than other students. Previous studies suggest that an elective course might be more effective in raising entrepreneurial intentions due to self-selection bias (Rideout and Gray, 2013). However, the findings of this study suggest a more nuanced picture of self-selection: while such a pre-educational bias towards higher entrepreneurial intentions appears to inflate the inspiration scores of students who take the entrepreneurship course as part of a specialization, this is not the case for students who take an entrepreneurship course as a stand-alone elective. This implies that students are as likely to enroll in an elective entrepreneurship course out of genuine interest as for trivial reasons, such as their friends taking it or thinking that the course is 'at least not boring' or 'easy to pass'. In contrast, it is only when the course is part of a wider entrepreneurship program, a heavier commitment that the student presumably has made voluntarily, that emotional conditioning towards entrepreneurship becomes more probable. In sum, elective courses, that are not part of a wider entrepreneurship program, bear less risk of selection bias than previously thought.

\section{Practical Implications}

This research suggests several practical implications for entrepreneurship trainers and educators. First, the observation that receptiveness to inspiration was significantly higher for participants with actual entrepreneurial experience provides support for the inclusion of more action-based personality development modules in entrepreneurship education, which until now focuses mostly on knowledge and hard skills (Kerr et al., 2018). As Hudson and Fraley (2015) found, volitional personality trait change is not impossible; with the right interventions, people can change their personality traits if they want. This requires transforming the entrepreneurship program, training, or course into an (almost) real entrepreneurial experience, by emulating typical characteristics of 
the entrepreneurial context, such as risk, limited resources, and information ambiguity, in the learning environment (cf. Nabi et al., 2017). Being active in entrepreneurship makes individuals adopt, practice and reinforce entrepreneurial traits (Frese and Rauch, 2008; Mitchell et al., 2002). Expectations of success should remain modest, though. Willingness to change appears to be a prerequisite (Hudson and Fraley, 2015) and even then personality traits remain notoriously stable; experiences need to be life-altering to have an impact (Roberts and Mroczek, 2008).

Second, the study illustrates that increasing entrepreneurial inspiration is a worthwhile endeavor. It summarizes how entrepreneurial inspiration can raise individuals' overall self-esteem (Thrash and Elliot, 2004), stimulate the actualization of creative ideas (Thrash et al., 2010), increase productivity (Thrash et al., 2014), and enhance the recognition, elaboration and enactment of entrepreneurial opportunities (Wartiovaara et al., 2018). In addition, it shows how entrepreneurial inspiration can raise (inexperienced) individuals' entrepreneurial intentions, which can translate to more venture creation (Elert et al., 2015; Rauch and Hulsink, 2015). However, attempts to increase entrepreneurial inspiration require more than superlative course elements, as triggers are highly idiosyncratic (McAdams 1982; Nabi et al., 2018). Instead of focusing on creating an inspirational course, entrepreneurship trainers and educators can better focus on creating an inspiration-conducive context. That is, the ambient entrepreneurial values, ideas, or opportunities need to grip students in a deep way, whereby the instructor functions as a facilitator who provides students with space to figure out what inspires each of them in particular (McNally et al., 2020). Individually, each student will have his or her own vision or goals (Van Ewijk and Weber, 2021), and the course should inspire them to bring them into fruition by means of entrepreneurship.

Finally, education or training institutions with the particular objective of increasing participants' entrepreneurial intentions would do well to focus on full-fledged specializations and programs in entrepreneurship, as these appear to be more effective than standalone courses. A larger motivational commitment from the start followed by a prolonged exposure to potential triggers of entrepreneurial inspiration, increases the likelihood of participants actually 'falling in love' with the idea of entrepreneurship as a future profession. In addition, if the goal is to increase participants' entrepreneurial intentions, efforts to inspire them will be more effective when explicitly targeting those without previous entrepreneurial experience. 


\section{Limitations and Future Research}

The respondents in the sample took entrepreneurship courses in different national and institutional contexts. Although preliminary analyses of the sample did not reveal any pattern that could be

directly related to the hypotheses, this does not exclude the possibility that contextual differences, such as culture, influence antecedents and effects of course-derived inspiration. Similarly, data on differences in course pedagogy, such as passive versus experiential teaching and learning strategies, were not included in the study, although these may moderate the relation between receptiveness to inspiration and course-derived entrepreneurial inspiration. Finally, entrepreneurial experience in this study focused on experiences by students themselves, as the literature emphasized the trait changing potential of such first-hand experiences. That said, experiencing the entrepreneurial success or failure of a family member, spouse, or friend, secondhand but in close proximity, could also constitute a life-altering experience. Exploring the role of these contextual and pedagogical factors, requires more research attention (cf. Nabi et al., 2017).

Future studies may also build on and extend the application of the Affect Infusion Model that was utilized in this research. For example, the model does not distinguish between moods and (discrete) emotions; its definition of affect encompasses both. Entrepreneurship researchers could explore whether the effect of discrete emotions is more temporal than that of moods. That is, do entrepreneurial intentions need to be translated into entrepreneurial behavior, perhaps facilitated by actual opportunity recognition and perceived entrepreneurial self-efficacy, quickly - before entrepreneurial inspiration wanes? Do entrepreneurial intentions that are heightened by entrepreneurial inspiration need additional reinforcement from other feeling traits (with more longevity than feeling states), such as passion (Gielnik et al., 2017), to preserve intensity over a longer period of time? Regarding individuals who are already entrepreneurs: does affect prime their 'intentions to continue being an entrepreneur' just as it seems to increase their venture creation efforts (Foo et al., 2009)?

Finally, future studies can test the effects of entrepreneurial inspiration on intention models, as proposed earlier in this discussion. This could include research designs comparing different types of programs and pedagogy. For example, Nabi et al. (2017) suggest the potential for competence-model pedagogical methods (emphasizing active problem solving in real-life situations and turning their abilities into competences) over other models. Future research could explore whether this type of pedagogy facilitates course-based entrepreneurial inspiration more 
than other types do, perhaps also looking at whether the maturity of students in terms of age or education level plays a role. As such, this research facilitates a range of avenues for emerging research on entrepreneurial inspiration as important entrepreneurial emotion.

\section{Conclusion}

This research was the first to provide a robust theoretical framework on entrepreneurial inspiration, and to empirically examine the relationship between receptiveness to inspiration, entrepreneurial inspiration, and entrepreneurial intentions amongst respondents with and without entrepreneurial experience. Inspired by Thrash and Elliot (2003), receptiveness to inspiration was introduced as a dispositional temperament or feeling trait (Keller and Kozlinska, 2019); a trait that facilitates entrepreneurship (Kerr et al., 2018) just as dispositional optimism (Crane and Crane, 2007), tolerance for ambiguity (Lackeus, 2014), and resilience (Korber and McNaughton, 2018) do.

Overall, the results suggest that receptiveness to inspiration is significantly higher among students with entrepreneurial experience although the baseline measurement (scores for students without entrepreneurial experience) was far from zero. This suggests that unexperienced individuals could also display this trait, whereby entrepreneurial experience enhances it further. In addition, the analyses indicate that receptiveness to inspiration was positively related to the emotional state of course-related entrepreneurial inspiration. Finally, the results reinforce the explanatory power of the Affect Infusion Model (Forgas, 1995) in confirming that course-derived entrepreneurial inspiration and entrepreneurial intentions are only positively related for students without entrepreneurial experience. 


\section{References}

Ajzen, I. (1991), “The theory of planned behavior”, Organizational Behavior and Human Decision Processes, Vol. 38 No. 1, pp. 95-109.

Allport, G.W. and Odbert, H.S. (1936), "Trait-names: A psycho-lexical study”, Psychological Monographs, Vol. 47, pp. 1-93.

Baron, R.A. (2008), "The role of affect in the entrepreneurial process," Academy of Management Review, Vol. 33 No. 2, pp. 328-340.

Baron, R.A. (2014), Essentials of Entrepreneurship: Evidence and Practice, Edward Elgar Publishing, Cheltenham UK.

Barsade, S.G. and Gibson, D.W. (2007), "Why does affect matter in organisations?" Academy of Management Perspectives, Vol. 21 No. 1, pp. 36-59.

Blake Hylton, J., Mikesell, D., Yoder, J.D. and LeBlanc, H. (2020), "Working to Instill the Entrepreneurial Mind-Set Across the Curriculum", Entrepreneurship Education and Pedagogy Vol. 3 No. 1, pp. 86-106.

Blenker, P., Elmholdt, S.T., Frederiksen, S.H., Korsgaard, S. and Wagner, K. (2014), "Methods in entrepreneurship education research: A review and integrative framework", Education + Training, Vol. 56, pp. 697-715.

Bloemen Bekx, M., Voordeckers, W., Remery, C. and Schippers, J. (2019), "Following in parental footsteps? The influence of gender and learning experiences on entrepreneurial intentions", International Small Business Journal, Vol. 37 No. 6, pp. 642-663.

Brandstätter, H. (2011), "Personality aspects of entrepreneurship: A look at five meta-analyses", Personality and Individual Differences, Vol. 51 No. 3, pp. 222-230.

Cardon, M.S., Foo, M.D., Shepherd, D. and Wiklund, J. (2012), "Exploring the Heart: Entrepreneurial Emotion Is a Hot Topic”, Entrepreneurship Theory and Practice, Vol. 36 No. 1, pp. 1-10.

Clarke, T. (1997), The Theory of Inspiration: composition as a crisis of subjectivity in romantic and post-romantic writing, Manchester University Press, New York NY.

Clausen, T.H. (2020), "Entrepreneurial thinking and action in opportunity development: A conceptual process model”, International Small Business Journal, Vol. 38 No. 1, pp. 21-40.

Clore, G.L., Gaspar, K. and Garvin, E. (2001), “Affect as Information”, Forgas, J.P. (Ed.), Handbook of Affect and Social Cognition, Erlbaum, Mahwah NJ, pp. 121-144. 
Conley, J.J. (1985), "Longitudinal stability of personality traits: A multitrait-multimethod- multioccasion analysis", Journal of Personality and Social Psychology, Vol. 49 No. 5, pp. 12661282.

Crane, F.G. and Crane, E.C. (2007), "Dispositional Optimism and Entrepreneurial Success", The Psychologist-Manager Journal, Vol. 10 No. 1, pp. 13-25.

Davis, M.A., Kirby, S.L. and Curtis, M.B. (2007), “The influence of affect on goal choice and task performance", Journal of Applied Social Psychology, Vol. 37 No. 1, pp. 14-42.

Elert, N., Andersson, F.W. and Wennberg, K. (2015), “The impact of entrepreneurship education in high school on long-term entrepreneurial performance", Journal of Economic Behavior and Organization, Vol. 111 March, pp. 209-223.

Fayolle, A., Verzat, C. and Wapshott, R. (2016), "In quest of legitimacy: The theoretical and methodological foundations of entrepreneurship education research", International Small Business Journal, Vol. 34 No. 7, pp. 895-904.

Foo, M.D., Uy, M.A. and Baron, R.A. (2009), "How do feelings influence effort? An empirical study of entrepreneurs' affect and venture effort", Journal of Applied Psychology, Vol. 94 No. 4, pp. 1086-1094.

Forgas, J.P. (1995), “Mood and judgment: The Affect Infusion Model”, Psychological Bulletin, Vol. 117 No. 1, pp. 39-66.

Frese, M. and Rauch, A. (2008), "A Personality Approach to Entrepreneurship", Cartwright, S. and Cooper, C.L. (Ed.s), The Oxford Handbook of Personnel Psychology, Oxford University Press, Oxford UK, pp. 121-136.

Gielnik, M.M., Uy, M.A., Funken, R. and Bischoff, K.M. (2017), „Boosting and sustaining passion: A long-term perspective on the effects of entrepreneurship training", Journal of Business Venturing, Vol. 32 No. 3, pp. 334-353.

Grichnick, D., Smeja, A. and Welpe, I. (2010), “The importance of being emotional: How do emotions affect entrepreneurial opportunity evaluation and exploitation?" Journal of Economic Behavior and Organization, Vol. 76 No. 1, pp. 15-29.

Haddoud, M.Y., Onjewu, A.E., Nowinski, W. and Alammari, K. (2020), “Assessing the role of entrepreneurship education in regulating emotions and fostering implementation intention: evidence from Nigerian universities", Studies in Higher Education, ahead of print - DOI: $10.1080 / 03075079.2020 .1758652$ 
Haidt, J. (2000), “The positive emotion of elevation”, Prevention and Treatment, Vol. 3 No. 1, Article 3c. DOI: 10.1037/1522-3736.3.1.33c

Heckman, J.J. (2008), “Schools, skills, and synapses”, Economic Inquiry. Vol. 46 No. 3, pp. 289324.

Hudson, N.W. and Haley, R.C. (2015), "Volitional Personality Trait Change: Can People Choose to Change Their Personality Traits?” Journal of Personality and Social Psychology, Vol. 109 No. 3, pp. 490-507.

Keller, P.G. and Kozlinska, I. (2019), "Entrepreneurial Affect and Emotions in Entrepreneurship

Education Impact Research: A Systematic Review and Research Agenda", Entrepreneurship Education and Pedagogy, Vol. 2 No. 4, pp. 281-307.

Keltner, D. and Haidt, J. (2003), "Approaching awe, a moral, spiritual, and aesthetic emotion", Cognition and Emotion, Vol. 17 No. 2, pp. 297-314.

Kerr, S.P., Kerr, W.R. and Xu, T. (2018), "Personality Traits of Entrepreneurs: A Review of Recent Literature", Foundations and Trends in Entrepreneurship, Vol. 14 No. 3, pp. 279-356.

Kolvereid, L. (1996), “Organisational employment versus self employment: reasons for career choice intentions", Entrepreneurship Theory and Practice, Vol. 20 No. 3, pp. 23-31.

Korber, S. and McNaughton, R.B. (2018), "Resilience and entrepreneurship: a systematic literature review", International Journal of Entrepreneurial Behavior and Research Vol. 24 No. 7, pp. 1129-1154.

Krueger, N.F., Reilly, M. and Carsrud, A.L. (2000), "Competing models of entrepreneurial intentions", Journal of Business Venturing, Vol. 15 No. 5/6, pp. 411-532.

Krueger, N. (2017), "Entrepreneurial Intentions are Dead: Long Live Entrepreneurial Intentions”, Carsrud, A.L. and Brännback, M. (Ed.s), Revisiting the Entrepreneurial Mind, Springer, Cham, pp. 13-34.

Kuratko, D.F. (2010), Entrepreneurship: Theory, Process, Practice (10 ${ }^{\text {th }}$ edition), Cengage Learning, Boston MA.

Lackeus. M. (2014), “An emotion based approach to assessing entrepreneurial education”, The International Journal of Management Education, Vol. 12 No. 3, pp. 374-396.

Liñán, F. and Chen, Y.W. (2009), "Development and cross-cultural application of a specific instrument to measure entrepreneurial intentions", Entrepreneurship Theory and Practice, Vol. 33 No. 3, pp. 593-617. 
Lorz, M., Mueller, S. and Volery, T. (2013), "Entrepreneurship education: a systematic review of the methods in impact studies”, Journal of Enterprising Culture, Vol. 21 No. 2, pp. 123-151.

McAdams, D.P. (1982), "Experiences of intimacy and power: Relationships between social motives and autobiographical memory”, Journal of Personality and Social Psychology, Vol. 52 No. 2, pp. 292-302.

McNally, J.J., Piperopoulos, P., Welsh, D.H.B., Mengel, T., Tantawy, M. and Papageorgiadis, N. (2020), "From pedagogy to andragogy: Assessing the impact of social entrepreneurship course syllabi on the Millennial learner", Journal of Small Business Management, Vol. 58 No. 5, pp. 871-892.

McNeish, D. M., and Stapleton, L. M. (2016), “The effect of small sample size on two-level model estimates: A review and illustration", Educational Psychology Review, Vol. 28 No. 2, pp. 295314.

Mitchell, R.K., Busenitz, L., Lant, T., McDougall, P.P., Morse, E.A. and Smith, J.B. (2002), "Toward a Theory of Entrepreneurial Cognition: Rethinking the People Side of Entrepreneurship Research”, Entrepreneurship Theory and Practice, Vol. 27 No. 2, pp. 93-104.

Nabi, G., Walmsley, A., Liñán, F., Akhtar, I. and Neame, C. (2018), "Does entrepreneurship education in the first year of higher education develop entrepreneurial intentions? The role of learning and inspiration", Studies in Higher Education, Vol. 43 No. 3, pp. 452-467.

Nabi, G., Liñán, F., Krueger, N., Fayolle, A. and Walmsley, A. (2017), "The impact of entrepreneurship education in higher education: A systematic review and research agenda", Academy of Management Learning and Education, Vol. 16 No. 2, pp. 277-299.

Paccagnella, O. (2011), "Sample size and accuracy of estimates in multilevel models: New simulation results", Methodology: European Journal of Research Methods for the Behavioral and Social Sciences, Vol. 7 No. 3, pp. 111-120.

Pittaway, L. and Cope, J. (2007), "Entrepreneurship Education. A Systematic Review of the Evidence", International Small Business Journal, Vol. 25 No. 5, pp. 479-510.

Rae, D. (2000), “Understanding entrepreneurial learning: a question of how?" International Journal of Entrepreneurial Behavior and Research, Vol. 6 No. 3, pp. 145-159.

Rauch, A. and Hulsink, W. (2015), "Putting Entrepreneurship Education Where the Intention to Act Lies: An Investigation Into the Impact of Entrepreneurship Education on Entrepreneurial Behavior," Academy of Management Learning and Education. Vol. 14 No. 2, pp. 187-204. 
Rideout, E.C. and Gray, D.O. (2013), "Does Entrepreneurship Education Really Work? A Review and Methodological Critique of the Empirical Literature on the Effects of University-Based Entrepreneurship Education”, Journal of Small Business Management, Vol. 51 No. 3, pp. 329351.

Rivis, A., Sheeran, P. and Armitage, C.J. (2009), "Expanding the affective and normative components of the Theory of Planned Behavior: A Meta-Analysis of anticipated affect and moral norms", Journal of Applied Psychology, Vol. 39 No. 12, pp. 2985-3019.

Roberts, B.W. and DelVecchio, W.F. (2000), "The rank-order consistency of personality traits from childhood to old age: A quantitative review of longitudinal studies", Psychological Bulletin, Vol 126 No. 1, pp. 3-25.

Roberts, B.W., Walton, K.E. and Viechtbauer, W. (2006), "Patterns of mean-level change in personality traits across the life course: A meta-analysis of longitudinal studies”, Psychological Bulletin, Vol. 132 No. 1, pp. 1-25.

Roberts, B.W. and Mroczek, D. (2008), "Personality Trait Change in Adulthood", Current Directions in Psychological Science, Vol. 17 No. 1, pp. 31-35.

Schoeneberger, J.A. (2016), "The Impact of Sample Size and Other Factors When Estimating Multilevel Logistic Models", The Journal of Experimental Education, Vol. 84 No. 2, pp. 373379.

Shapero, A. and Sokol, L. (1982), “The Social Dimensions of Entrepreneurship”, Kent, C., Sexton, D. and Vesper, K. (Ed.s), Encyclopedia of Entrepreneurship, Prentice Hall, Englewood Cliffs NJ, pp. 72-90.

Souitaris, V., Zerbinati, S. and Al-Laham, A. (2007), "Do entrepreneurship programmes raise entrepreneurial intentionion of science and engineering students? The effect of learning, inspiration and resources", Journal of Business Venturing, Vol. 22 No. 4, pp. 566-591.

Springer, K. (2009), Educational Research: A Contextual Approach, Wiley, Hoboken NJ.

Thompson, E. (2009), "Individual Entrepreneurial Intent: Construct Clarification and Development of an Internationally Reliable Metric", Entrepreneurship Theory and Practice, Vol. 33 No. 3, pp. 669-94.

Thrash, T.M. and Elliot, A.J. (2003), "Inspiration as a Psychological Construct", Journal of Personality and Social Psychology, Vol. 84 No. 4, pp. 871-889. 
Thrash, T.M. and Elliot, A.J. (2004), "Inspiration: Core Characteristics, Component Processes, Antecedents, and Function”, Journal of Personality and Social Psychology, Vol. 87 No. 6, pp. 957-973.

Thrash, T.M., Maruskin, L.A., Cassidy, S.E., Fryer, J.W. and Ryan, R.M. (2010), "Mediating between the muse and the masses: Inspiration and the actualization of creative ideas", Journal of Personality and Social Psychology, Vol. 98 No. 3, pp. 469-487.

Thrash, T.M., Moldovan, E.G., Oleynick, V.C. and Maruskin, L.A. (2014), “The Psychology of Inspiration", Social and Personality Psychology, Vol. 8 No. 9, pp. 495-510.

Van Ewijk, A.R. and Belghiti-Mahut, S. (2019), "Context, gender and entrepreneurial intentions: how entrepreneurship education changes the equation", International Journal of Gender and Entrepreneurship, Vol. 11 No. 1, pp. 75-98.

Van Ewijk, A.R. and Weber, W. (2021), “The Value of Knowing What You Want: Goal Hierarchy and Entrepreneurial Intentions", Journal of Business Venturing Insights, Vol. 15 June, ahead of print. DOI: 10.1016/j.jbvi.2020.e00215

Wartiovaara, M., Lahti, T. and Wincent, J. (2019), "The role of inspiration in entrepreneurship: Theory and the future research agenda", Journal of Business Research, Vol. 101, pp. 548-554.

Westhead, P. and Solesvik, M.Z. (2016), "Entrepreneurial education and entrepreneurial intention:

Do female students benefit?” International Small Business Journal, Vol. 34 No. 8, pp. 9791003.

Williams, M.H. (1997), "Inspiration: A psychoanalytic and aesthetic concept", British Journal of Psychology, Vol. 14 No. 1, pp. 33-43. 
Figure 1.

\section{Conceptual Model and Hypothesized Relationships}

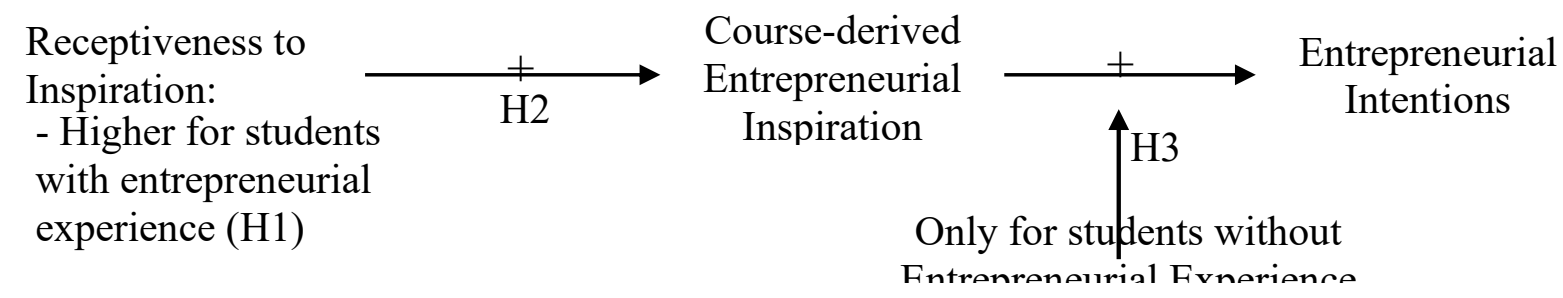




\section{Table I}

Study Sample Characteristics $(\mathrm{N}=342)$

\begin{tabular}{lll}
\hline Characteristics & Categories & N (percentage) \\
\hline Student & & \\
Age & Range: 19-41 years & \\
& Mean: 24 years / SD: 5 years \\
Gender & Female & $160(46.8 \%)$ \\
& Male & $177(51.8 \%)$ \\
& Unknown* & $5(1.5 \%)$ \\
College & Business & $176(51.5 \%)$ \\
& Engineering & $81(23.7 \%)$ \\
& Other & $47(13.7 \%)$ \\
Course Selection Mode & Compnown* & $38(11.1 \%)$ \\
& Elective & $126(36.8 \%)$ \\
Course is Part of an & Unknown* & $202(59.1 \%)$ \\
Entrepreneurship & Yes & $14(4.1 \%)$ \\
Program / Major & Unknown* & $144(42.1 \%)$ \\
& & $146(42.7 \%)$ \\
\hline
\end{tabular}

\section{Course}

Course Titles

Business Start-up and Growth / Creating a New Business / Development of Social Sustainable Enterprises / Entrepreneur Laboratory / Entrepreneurial Skills workshop / Entrepreneurship / Entrepreneurship and New Venture Management / Entrepreneurship and Small Business Management / Entrepreneurship Management / Entrepreneurship Policy and Enterprise Promotion / Fundamentals of Innovation and Entrepreneurship / Innovation and Entrepreneurship / Managing Technology, Innovation and Change through Entrepreneurship / New Technology Business Development / Special Topics in Management (Innovation and Entrepreneurship)

$\begin{array}{llll}\text { Course Study Level } & \text { Undergraduate } & 268(78.4 \%) & \\ & \text { Postgraduate } & 60(17.5 \%) & \\ & \text { Unknown* } & 14(4.1 \%) & \\ \text { Country institution / N / } & \text { United Arab Emirates } & 70(20.5 \%) & \mathrm{A}(19) \mathrm{B}(17) \mathrm{C}(28) \mathrm{D}(16) \\ \text { Institutions (N) } & \text { United States } & 53(15.5 \%) & \mathrm{A}(15) \mathrm{B}(38) \\ & \text { The Netherlands } & 44(12.9 \%) & \mathrm{A}(25) \mathrm{B}(19) \\ & \text { Argentina } & 39(11.4 \%) & \mathrm{A}(39) \\ & \text { Australia } & 36(10.5 \%) & \mathrm{A}(36) \\ & \text { Malaysia } & 31(9.1 \%) & \mathrm{A}(31) \\ & \text { Finland } & 25(7.3 \%) & \mathrm{A}(15) \mathrm{B}(10) \\ & \text { Kenya } & 25(7.3 \%) & \mathrm{A}(25) \\ & \text { Belgium } & 19(5.6 \%) & \mathrm{A}(19)\end{array}$

* Responses were given at the start and at the end of the course; answers that differed were excluded. For example, a student who indicated 'Yes' to the course being part of a wider entrepreneurship program or major at the start of the course, but 'No' at the end of the course. 


\section{Table II}

\section{Descriptive Statistics and Pearson Correlations: Main and Control Variables (Total}

Sample)

\begin{tabular}{|c|c|c|c|c|c|c|c|c|c|c|c|c|}
\hline Variables & $\mathrm{N}^{\mathrm{a}}$ & $\begin{array}{c}\text { Cumulative } \\
\text { Mean }\end{array}$ & Standard & 1 & $?$ & 2 & 4 & 5 & 6 & 7 & 8 & 9 \\
\hline 1. Receptiveness to & 271 & 40.03 & 7.34 & 1 & & & & & & & & \\
\hline $\begin{array}{l}\text { 2. Receptiveness to } \\
\text { Inspiration (end course) }\end{array}$ & 237 & 40.90 & 6.68 & $.63 * * *$ & 1 & & & & & & & \\
\hline $\begin{array}{l}\text { 3. Entrepreneurial } \\
\text { Intentions (start course) }\end{array}$ & 298 & 25.93 & 6.14 & $.38 * * *$ & $.25^{* * *}$ & 1 & & & & & & \\
\hline $\begin{array}{l}\text { 4. Entrepreneurial } \\
\text { Intentions (end course) }\end{array}$ & 276 & 25.94 & 6.38 & $.36 * * *$ & $.29 * * *$ & $.39 * * *$ & 1 & & & & & \\
\hline $\begin{array}{l}\text { 5. Entrepreneurial } \\
\text { Experience (start course) }\end{array}$ & 311 & 1.38 & .49 & $.20^{* *}$ & $.24 * * *$ & $.39 * * *$ & $.41 * * *$ & 1 & & & & \\
\hline $\begin{array}{l}\text { 6. Course-derived } \\
\text { Entrepreneurial Inspiration } \\
\text { (end course) }\end{array}$ & 326 & 11.07 & 2.63 & $.26 * * *$ & $.21^{* *}$ & $.49 * * *$ & $.56^{* * *}$ & $.22 * * *$ & 1 & & & \\
\hline $\begin{array}{l}\text { 7. Course Study Level } \\
\text { (Undergrad / Postgrad) }\end{array}$ & 328 & 1.18 & .39 & -.01 & -.02 & $-.14^{*}$ & -.08 & .02 & -.06 & 1 & & \\
\hline $\begin{array}{l}\text { 8. Course as Part of } \\
\text { Program (No / Yes) }\end{array}$ & 290 & 1.50 & .50 & $.21^{* *}$ & $.20^{* *}$ & $.18^{* *}$ & .12 & .07 & $.17^{* *}$ & $-.22 * *$ & 1 & \\
\hline $\begin{array}{l}\text { 9. Course Selection Mode } \\
\text { (Mandatory / Elective) }\end{array}$ & 328 & 1.62 & .49 & -.01 & -.11 & -.02 & $-.13^{*}$ & -.02 & .02 & $.19^{*}$ & -.08 & 1 \\
\hline $\begin{array}{l}\text { 10. Student Gender } \\
\text { (Female / Male) }\end{array}$ & 337 & 1.53 & .50 & .06 & .06 & $.18^{*}$ & $.14^{*}$ & $.23 * *$ & .05 & .03 & .09 & .03 \\
\hline
\end{tabular}

a. Sample sizes per measure vary as a function of missing data after data cleaning.

Note: ${ }^{* *} p<0.01,{ }^{* * *} p<0.001$. 
Table III

Independent Samples T-Test: Receptiveness to Inspiration for Students With and Without Entrepreneurial Experience (Start Course)

\begin{tabular}{|c|c|c|c|c|c|c|c|}
\hline & \multicolumn{3}{|c|}{$\begin{array}{c}\text { Students with } \\
\text { entrepreneurial experience }\end{array}$} & \multicolumn{3}{|c|}{$\begin{array}{c}\text { Students without } \\
\text { entrepreneurial experience }\end{array}$} & \multirow{2}{*}{$\begin{array}{c}\text { Mean } \\
\text { difference }\end{array}$} \\
\hline & $\mathrm{N}$ & Mean & S. D. & $\mathrm{N}$ & Mean & S.D. & \\
\hline Start course & 99 & 41.09 & 9.09 & 171 & 38.77 & 7.50 & $-2.32 *$ \\
\hline
\end{tabular}

Note: ${ }^{*} p<.05$ 
Table IV

Multiple Hierarchical Regression Analysis: Receptiveness to Inspiration (Start of Course) on Course-Derived Entrepreneurial Inspiration

\begin{tabular}{lcc}
\hline Variables & $\begin{array}{c}(1) \\
\text { Course-derived } \\
\text { Entrepreneurial Inspiration }\end{array}$ & $\begin{array}{c}(2) \\
\text { Course-derived } \\
\text { Entrepreneurial Inspiration }\end{array}$ \\
\hline Study Level & & .27 \\
Selection Mode & $(.46)$ & $(.51)$ \\
Gender & .02 & -.15 \\
& $(.36)$ & $(.40)$ \\
Part Program & .28 & .09 \\
& $(.35)$ & $.38)$ \\
Receptiveness to Inspiration (start course) & $.89^{*}$ & $.91 *$ \\
& $(.35)$ & $.40)$ \\
Constant & & $.10 * * *$ \\
& & $(.03)$ \\
Observations & & $5.40^{* * *}$ \\
R--squared & $9.06^{* * *}$ & $(1.55)$ \\
Adjusted R-squared & $(1.08)$ & 201 \\
\end{tabular}

Note: ${ }^{*} p<.05,{ }^{* *} p<.01,{ }^{* * *} p<.001$. 


\section{Table V}

Hierarchical Regression Analysis: Course-Derived Entrepreneurial Inspiration on Entrepreneurial Intentions, End Of Course, with Entrepreneurial Experience (Whole Sample, Interaction Effect)

\begin{tabular}{lcccc}
\hline Variables & $(1)$ & $(2)$ & $(3)$ & $(4)$ \\
\hline EI start course & $.85^{* * *}$ & $.76^{* * *}$ & $.74^{* * *}$ & $.723^{* * *}$ \\
Selection Mode & $.04)$ & $(.05)$ & $(.05)$ & $(.05)$ \\
Study level & -.82 & -.78 & -.78 & -.82 \\
& $(.53)$ & $(.50)$ & $(.50)$ & $(.50)$ \\
Part Program & .42 & .30 & .22 & .09 \\
& $(.64)$ & $(.61)$ & $(.61)$ & $(.61)$ \\
Gender & .55 & .28 & .28 & .29 \\
& $(.52)$ & $(.50)$ & $(.50)$ & $(.49)$ \\
Course-derived Entrepreneurial Inspiration & .42 & .40 & .33 & .30 \\
& & $.46)$ & $(.49)$ & $(.48)$ \\
Entrepreneurial Experience & & $(.10)$ & $.46^{* * *}$ & $1.01^{* *}$ \\
& & & .54 & $(.29)$ \\
Course-derived Entrepreneurial Inspiration & & & $(.53)$ & $(2.34)$ \\
x Entrepreneurial Experience & & & & $-.40^{*}$ \\
Constant & & & & $(.19)$ \\
& 3.03 & .81 & .74 & -4.91 \\
Observations & $(1.96)$ & $(1.93)$ & $(1.93)$ & $(3.36)$ \\
R-squared & 198 & 198 & 198 & 198 \\
Adjusted R-squared & .70 & .73 & .73 & .74 \\
\hline
\end{tabular}

Note: ${ }^{*} p<0.05,{ }^{* *} p<0.01,{ }^{* * *} p<0.001$. 


\section{Table VI}

Hierarchical Regression Analysis: Course-Derived Entrepreneurial Inspiration on Entrepreneurial Intentions, End Of Course (Sample Split by Entrepreneurial Experience)

\begin{tabular}{|c|c|c|c|c|}
\hline & \multicolumn{2}{|c|}{$\begin{array}{c}\text { Students without } \\
\text { entrepreneurial experience }\end{array}$} & \multicolumn{2}{|c|}{$\begin{array}{c}\text { Students with } \\
\text { entrepreneurial experience }\end{array}$} \\
\hline Variables & $(1)$ & $(2)$ & (2) & (3) \\
\hline EI start course & $\begin{array}{l}.91^{* * *} \\
(.05)\end{array}$ & $\begin{array}{c}.78 * * * \\
(.05)\end{array}$ & $\begin{array}{c}.64 * * * \\
(.10)\end{array}$ & $\begin{array}{c}.61 * * * \\
(.10)\end{array}$ \\
\hline Selection Mode & $\begin{array}{l}-.37 \\
(.60)\end{array}$ & $\begin{array}{l}-.35 \\
(.55)\end{array}$ & $\begin{array}{r}-1.55 \\
(.94)\end{array}$ & $\begin{array}{r}-1.47 \\
(.93)\end{array}$ \\
\hline Study level & $\begin{array}{l}.16 \\
(.77)\end{array}$ & $\begin{array}{l}-.54 \\
(.72)\end{array}$ & $\begin{array}{l}.83 \\
(1.08)\end{array}$ & $\begin{array}{c}1.02 \\
(1.08)\end{array}$ \\
\hline Part Program & $\begin{array}{l}.98 \\
(.58)\end{array}$ & $\begin{array}{c}.62 \\
(.54)\end{array}$ & $\begin{array}{l}-.22 \\
(.93)\end{array}$ & $\begin{array}{l}-.41 \\
(.93)\end{array}$ \\
\hline Gender & $\begin{array}{l}.03 \\
(.58)\end{array}$ & $\begin{array}{l}-.09 \\
(.53)\end{array}$ & $\begin{array}{l}.54 \\
(.94)\end{array}$ & $\begin{array}{l}.56 \\
(.93)\end{array}$ \\
\hline Course-derived & & $.55 * * *$ & & .31 \\
\hline $\begin{array}{l}\text { Entrepreneurial Inspiration } \\
\text { Constant }\end{array}$ & $\begin{array}{c}.82 \\
(2.25)\end{array}$ & $\begin{array}{c}(.11) \\
-.33 \\
(2.07)\end{array}$ & $\begin{array}{l}11.29 \\
(4.06)\end{array}$ & $\begin{array}{c}(.19) \\
8.43 \\
(4.38)\end{array}$ \\
\hline $\begin{array}{l}\text { Observations } \\
\text { R-squared } \\
\text { Adjusted R-squared }\end{array}$ & $\begin{array}{l}116 \\
.79 \\
.78\end{array}$ & $\begin{array}{l}116 \\
.83 \\
.82\end{array}$ & $\begin{array}{l}82 \\
.40 \\
.36\end{array}$ & $\begin{array}{l}82 \\
.43 \\
.38\end{array}$ \\
\hline
\end{tabular}

Note: ${ }^{* * *} p<0.001$ 


\section{Table VII}

Independent Samples T-Test: Entrepreneurial Intentions at the Start of the Course for Students Not Taking and Course as Part of an Entrepreneurship Program and Students Who Do

\begin{tabular}{|c|c|c|c|c|c|c|c|}
\hline & \multicolumn{3}{|c|}{$\begin{array}{l}\text { Students not taking the } \\
\text { course as part of program }\end{array}$} & \multicolumn{3}{|c|}{$\begin{array}{c}\text { Students taking the } \\
\text { course as part of program }\end{array}$} & \multirow{2}{*}{$\begin{array}{c}\text { Mean } \\
\text { difference }\end{array}$} \\
\hline & $\mathrm{N}$ & Mean & S. D. & $\mathrm{N}$ & Mean & S.D. & \\
\hline $\begin{array}{l}\text { Entrepreneurial intentions } \\
\text { (start course) }\end{array}$ & 120 & 24.82 & 6.36 & 132 & 27.02 & 5.64 & $-2.21 * *$ \\
\hline
\end{tabular}

Note: ${ }^{* *} p<.01$ 
Table VIII

Independent Samples T-Test: Course-Derived Entrepreneurial Inspiration for Students Not Taking the Course as Part of an Entrepreneurship Program and Students Who Do

\begin{tabular}{|c|c|c|c|c|c|c|c|}
\hline & \multicolumn{3}{|c|}{$\begin{array}{l}\text { Students not taking the } \\
\text { course as part of program }\end{array}$} & \multicolumn{3}{|c|}{$\begin{array}{l}\text { Students taking the } \\
\text { course as part of program }\end{array}$} & \multirow{2}{*}{$\begin{array}{c}\text { Mean } \\
\text { difference }\end{array}$} \\
\hline & $\mathrm{N}$ & Mean & S. D. & $\mathrm{N}$ & Mean & S.D. & \\
\hline $\begin{array}{l}\text { Course-derived } \\
\text { entrepreneurial inspiration }\end{array}$ & 128 & 10.70 & 2.93 & 139 & 11.59 & 2.30 & $-.90 * *$ \\
\hline
\end{tabular}

Note: ${ }^{* *} p<.01$ 